\title{
Food resources used by three species of fish in the semi-arid region of Brazil
}

\author{
Márcio J. da Silva1, Bruno R. S. Figueiredoํㅜ, Robson T. C. Ramos ${ }^{1,2}$ \\ and Elvio S. F. Medeiros ${ }^{1}$
}

Temporary and semi-permanent aquatic habitats in semi-arid Brazil have been reported as important sites supporting a diverse fish fauna. As such, they must be able to trophically sustain fish species that feed at different trophic levels. This study aims to describe the diets of Astyanax aff. bimaculatus, Hoplias malabaricus and Prochilodus brevis in aquatic systems in semiarid Brazil, providing evidence of the importance of these habitats as supporters of large consumers like fish. The diet of the three species studied was diverse, feeding on a range of food items, from microalgae to fish. Despite that, a few items were more important to each of the study species. These results and the relatively high rates of stomach fullness indicate that a diverse and abundant food range is available in the study sites, but species seem to select some food resources. The present study provides evidence that despite being highly variable, intermittent and semi-permanent aquatic systems in semi-arid Brazil are able to trophically sustain large consumers.

Os ambientes aquáticos temporários e semi-permanentes do semiárido brasileiro tem sido mostrados como importantes sítios que possuem uma diversa fauna de peixes. Desta forma, esses ambientes devem ser capazes de sustentar, do ponto de vista trófico, populações de peixes que se alimentam em diversos níveis tróficos. O presente estudo tem como objetivo descrever o hábito alimentar de Astyanax aff. bimaculatus, Hoplias malabaricus e Prochilodus brevis em ambientes aquáticos do semiárido brasileiro, fornecendo evidências da importância desses habitats para manutenção da diversidade de consumidores como os peixes. A composição da dieta das espécies estudadas foi diversificada, já que alimentaram-se de uma variedade de classes de itens, desde microalgas até peixes. Apesar disso, alguns itens foram mais importantes para cada uma das três espécies. Estes resultados, e as altas taxas de repleção dos estômagos, indicam que um abundante e diverso conjunto de itens alimentares está disponível nos ambientes estudados, embora as espécies tendam a selecionar alguns itens em detrimento de outros. Este estudo fornece evidência de que, apesar de altamente variáveis, sistemas aquáticos intermitentes e semi-permanentes do semiárido brasileiro são capazes de sustentar, do ponto de vista trófico, consumidores de topo.

Key words: Astyanax aff. bimaculatus, Hoplias malabaricus, Prochilodus brevis, Intermittent habitats, Caatinga.

\section{Introduction}

The fish fauna in Brazilian semi-arid aquatic systems has traditionally been reported as poor in species and with low endemism (Paiva \& Campos, 1995). However, recent studies have shown that the fish fauna in this region is highly diverse with a great number of endemic species (Leal et al., 2003; Rosa et al., 2003; Medeiros et al., 2006; Abel et al., 2008). These ecosystems have also been reported as supporters of important ecological processes that drive the complex patterns of biodiversity and enable coexistence of the diverse fauna (Maltchik, 1996; Medeiros \& Maltchik, 2001a). Despite that, the need for conservation of aquatic systems in semi-arid Brazil has been only recently recognized (Leal et al., 2005; Maltchik \& Medeiros, 2006).

Even though hot spots for fish biodiversity in semi-arid Brazil are represented by larger systems such as the São Francisco River (Rosa et al., 2003), smaller and less permanent systems such as intermittent streams, and to a lesser extent small reservoirs, also hold consistent numbers of fish species (Medeiros et al., 2006). These temporary aquatic habitats, which may dry out after long periods of low precipitation, have been reported as important breeding sites for fish species (Medeiros \& Maltchik, 2000; Chaves et al., 2009). In streams, the reproductive activity triggered by flooding and the combined

${ }^{1}$ Grupo de Ecologia de Rios do Semiárido, Universidade Estadual da Paraíba, Centro de Ciências Biológicas e Sociais Aplicadas. Campus V, 58020-540 João Pessoa, Paraíba, Brazil. elviomedeiros@uepb.edu.br

${ }^{2}$ Universidade Federal da Paraíba, Depto de Sistemática e Ecologia. CCEN, 58059-900 João Pessoa, Paraíba, Brazil. 
patterns of use of isolated pools during the dry season, enable a succession of species throughout the hydrological cycle, enhancing overall species diversity (Medeiros \& Maltchik, 2001b). In that sense, intermittent streams and semi-permanent reservoirs are expected to hold water and resources long enough to enable a diverse fauna of aquatic organisms to survive during dry periods (Magoulick \& Kobza, 2003).

Species of fish that feed at a wide range of trophic levels are common and abundant in intermittent semi-arid aquatic systems of Brazil. Among the most abundant native species at their specific trophic levels are the omnivorous Astyanax aff. bimaculatus (Linnaeus, 1758) and the detritivorous/iliophagous Prochilodus brevis Steindachner, 1874 (Medeiros et al., 2010). Large predator species are not abundant in intermittent aquatic systems of Brazil but the carnivorous Hoplias malabaricus (Bloch, 1794) is very common in these systems (Medeiros et al., 2010). Astyanax aff. bimaculatus has a relatively diverse diet that includes aquatic invertebrates, and insect larvae and nymphs (Gurgel et al., 2002). This species may also consume small amounts of aquatic and terrestrial vegetation, macrophytes and seeds (Meschiatti et al., 2000). Prochilodus brevis feeds mostly on a mixture of algae, detritus and sediment, with the algal contribution being dominated by microbenthic taxa (Soares \& Rosa, 1998). Hoplias malabaricus consumes aquatic insects and micro-crustaceans (when young) and fish (when adult) (Paiva, 1974).

To hold a diverse fauna, aquatic systems in semi-arid Brazil should be able to trophically sustain species that feed at several levels of the food web. Therefore, this study aims to describe the diets of $A$. aff. bimaculatus, H. malabaricus and $P$. brevis in intermittent streams and semi-permanent reservoirs in semi-arid Brazil. Feeding behavior of these species is relatively well known in other systems, but information on their diets and overall feeding habits in semiarid areas is scarce. Therefore, this paper provides important information to better understand aquatic systems in semiarid Brazil, and provides evidence on the importance of these habitats as supporters of large fish consumers.

\section{Material and Methods}

\section{Study area}

This study was performed in two different areas of the Brazilian semi-arid region (northeastern Brazil): Seridó/ Borborema and Buíque/Vale do Ipojuca (Tabarelli \& Silva, 2003) (Fig. 1). These areas are classified as being of extreme biological importance and were identified as priority areas for biodiversity conservation in the Caatinga Biome (Silva et al., 2003), because they present high diversity of species and endemism.

The Seridó/Borborema area is located in southern Rio Grande do Norte State (Fig. 1). Average annual temperature is $30.7^{\circ} \mathrm{C}$ and precipitation is $600 \mathrm{~mm}$ (Amorim et al., 2005). Rainfall is concentrated between January and April (Amorim et al., 2005). Altitude in Seridó/Borborema ranges between 100 and $800 \mathrm{~m}$ (Governo do Estado da Paraíba, 1985). The Buíque/Vale do Ipojuca area is located in central Pernambuco
State (Fig. 1). Average annual temperature and precipitation are $25^{\circ} \mathrm{C}$ and $1095.9 \mathrm{~mm}$ (respectively), with rainfall concentrated between April and June (Rodal et al., 1998). Altitude ranges between 800 and $1000 \mathrm{~m}$ (Rodal et al., 1998). The study area is located in the domain of the Tropical and Arid/Semi-arid (Aw, BWh, BSh) climate types (Köppen-Geiger climate classification) (Leal et al., 2003; Peel et al., 2007) and the most important hydrological characteristic in this region is the intermittency of surface water flow (Maltchik \& Medeiros, 2006). Streams and rivers are intermittent and smaller reservoirs dry out after long periods of drought. Natural temporary shallow lakes are also an important feature in the study area (Maltchik \& Medeiros, 2006). The Seridó/Borborema is drained mostly by the Piranhas-Açu River basin, with the Seridó River as the main affluent. Buíque/Vale do Ipojuca is drained mostly by the Ipanema River (an affluent of the São Francisco River) and the headwaters of the Una River, which drains east to the Atlantic Ocean (Fig. 1).

\section{Data sampling}

Six sites were selected to represent artificial and natural aquatic systems typical to the Brazilian semi-arid (Fig. 1). Sites consisted of three reservoirs created from stream impoundment and three intermittent streams. Each site was sampled on four occasions, twice during the wet season (in April and June 2006) and twice during the dry season (in September and December 2006). Stream sites presented surface water flow intermittently during the wet season and were reduced to disconnected pools during the dry season. Reservoirs decreased in volume continuously during the study period (see Medeiros et al., 2008 for further detail on the study sites).

Fish sampling was performed during daylight. Samples were collected using a short beach seine net (4 m long, $1.5 \mathrm{~m}$ high and $5 \mathrm{~mm} \mathrm{mesh}$ ), a long beach seine net ( $20 \mathrm{~m}$ long, $2 \mathrm{~m}$ high and $12 \mathrm{~mm}$ mesh), a set of gill nets ( $30 \mathrm{~m}$ long and $1.5 \mathrm{~m}$ high equally divided into three $10 \mathrm{~m}$ panels of 35,45 and 55 $\mathrm{mm}$ mesh) and a cast net (2.4 $\mathrm{m}$ high and $12 \mathrm{~mm} \mathrm{mesh})$ (Medeiros et al., 2010). Fish caught were fixed in $10 \%$ formalin in the field and later transferred to $75 \%$ ethanol and identified. Fish were collected under License No. 032-DIFAP/ IBAMA of 23 March 2006.

For the stomach content analysis, a maximum of 15 specimens of each study species was selected per sampling site and occasion. In the laboratory, each individual fish was measured $(\mathrm{cm})$ for the standard length (SL) and weighed $(\mathrm{g})$. For the dietary analysis, the stomach of each fish was removed, blotted, placed in a Petri dish and observed with a stereomicroscope for macroscopic analysis of contents. The degree of stomach fullness was visually estimated assigning a score between 0 (empty) and 100 (fully distended with food), reflecting percentages of stomach volume occupied by food (Medeiros \& Arthington, 2008a, 2008b). The proportional contribution of each class of food items to the diet of individual fish was estimated using Hyslop's (1980) indirect volumetric method, where stomach items belonging to each prey (or other food) category are lumped together and squashed to a uniform 


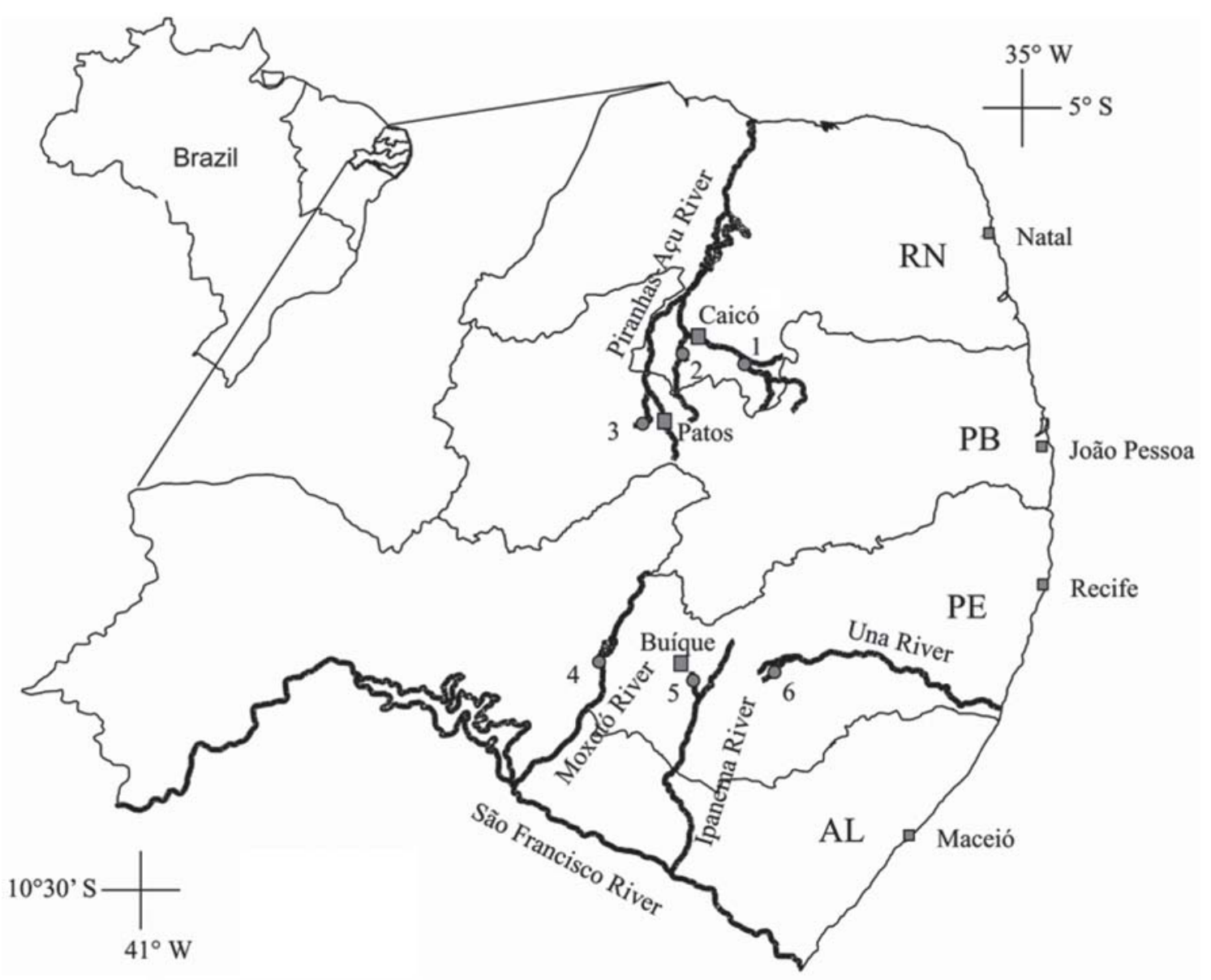

Fig. 1. Study areas showing Seridó/Borborema - RN/PB and Buíque/Vale do Ipojuca - PE. Towns and cities are denoted by squares. Study sites are: 1 - Seridó River, 2 - Cipó stream, 3 - Recanto Reservoir, 4 - Escama-Peixe stream, 5 - Mulungú Reservoir, and 6 - Gurjão Reservoir.

depth of $1 \mathrm{~mm}$; the area covered was taken to represent the volumetric contribution of that food category to the total stomach contents in $\mathrm{mm}^{3}$ (Arthington, 1992; Pusey et al., 2000).

For $P$. brevis further analysis was performed to evaluate composition of microscopic food items. After the macroscopic evaluation on stereomicroscope, the stomach content was diluted to a volume of $10 \mathrm{ml}$ with ethanol $70 \%$ and three sub-samples were analyzed using a binocular microscope. Microalgae were counted on three horizontal transects of the diluted stomach content mounted into an unsealed slide. Taxonomic classification of microalgae was based on Bicudo \& Menezes (2006).

\section{Data analysis}

For all analyses, only stomachs with fullness equal to or greater than $20 \%$ were considered in order to prevent bias in the calculation of the proportional contribution of each food category (Pusey et al., 1995). Items found in the diet were grouped into major food categories based on the type of food item (Microcrustaceans, Insects, Other arthropods, Other invertebrates, Vertebrates, Plant material, Other and Digested organic material). Among the digested organic material,
"Unidentified material" represented organic matter unidentifiable due to an advanced stage of digestion. Fragmented matter identified as being animal or vegetal but not taxonomically identifiable was termed "Organic matter". The category "Other" includes items referring to substrate, defined as Sand (granular crystals of sediment) and Sediment (fine particulate organic and inorganic material). To calculate the contribution of a given food item to the diet of a fish species, the average volume for that food item across all stomachs was calculated and then expressed as percentage. Frequency of occurrence (\%) was calculated as the number of times a food item occurred in the stomachs of a given species divided by the total number of stomachs analyzed.

Variation in diet composition of $A$. aff. bimaculatus between study sites (Seridó/Borborema and Buíque/Vale do Ipojuca) was investigated using Detrended Correspondence Analysis (DCA), because this species presented enough individuals to enable such analysis. Volume data was transformed to arcsine-square root to run the DCA, and Multi-Response Permutation Procedure (MRPP) (McCune \& Grace, 2002) was used to test for differences in diet composition between the two study areas. In the absence of differences, dietary data were pooled across study areas to 
increase sample sizes before performing MRPP on habitat types (stream and reservoir). For all MRPP analyses, the chancecorrected within group agreement (A) is presented as a measure of the degree of within group homogeneity, compared to random expectation. All analyses were performed on PC-ORD 4.27 (McCune \& Mefford, 1999). Unidentifiable material was excluded from statistical analysis to avoid bias (Pusey et al., 1995)

\section{Results}

A total of 355 stomachs were analyzed and 304 had fullness equal to or greater than $20 \%$. For the statistical analyses 8 stomachs were discarded because they presented only digested unidentified material (Table 1). Average size of fish showed some variation across sampling occasions and sites. Effects of size are taken into account hereafter and noted when appropriate. Higher rates of stomach fullness were observed for $P$. brevis and $A$. aff. bimaculatus for which only 18.0 and $13.7 \%$ of the stomachs analyzed, respectively, had fullness lower than 20\%. For $H$. malabaricus, $25 \%$ of stomachs had fullness lower than $20 \%$.

The richest diet was registered to $A$. aff. bimaculatus, with 35 food items distributed among eight food categories (Table 2). The volumetric composition consisted mainly of plant material and insects, although fish and microcrustaceans also contributed to the diet. Among insects, Diptera (larva) and Odonata (Anisoptera) were the most important (Table 2). Digested organic material and sand were well represented in the stomach contents of $A$. aff. bimaculatus. The frequency of occurrence of food items in the stomach contents followed the same pattern as the volume data.
Hoplias malabaricus also presented a diverse diet, with 22 food items distributed among seven of the eight food categories (Table 2). Despite that, only a few food categories contributed quantitatively to the diet (consider variation on fish size, Table 1). Fish and shrimp were the basis of the diet, with insects also being important. Among insects, Odonata nymph and fragments were the most important food items. The frequency of occurrence of food items in the stomach contents followed the same pattern as the volume data.

Macroscopic analysis on $P$. brevis stomach contents revealed that the basis of the diet was sediment and to a much lesser extent leaf fragments. Richness of food items was very low with only three food items observed across three of the eight food categories (Table 2). Food items other than sediment are most likely to be consumed accidentally, considering their very low volume and frequency. However, abundance data on microscopic items showed a high diversity of microalgae as part of the diet of P. brevis (Table 3). Chlorophyceae was the most diverse group followed by Bacillariophyceae and Cyanophyceae. Abundance of individuals was greater in Bacillariophyceae from which 34.0\% of the counted individuals (mostly Amphora) were registered.

Detrended Correspondence Analysis (DCA) run on dietary volumetric data of $A$. aff. bimaculatus showed a great deal of overlap among sampling occasions and sites (Fig. 2). Furthermore, the Multi-response Permutation Procedure showed that diet composition of $A$. aff. bimaculatus was not significantly different between the two study areas (Seridó/ Borborema and Buíque/Vale do Ipojuca) (MRPP, A = -0.006 and $p=0.55)$. This species also did not present significant

Table 1. Total number of fish caught (N), number of stomachs analyzed (A) and number of stomachs used (U) ( $>20 \%$ fullness) of each species in six sites located in the Brazilian semi-arid region. Fish sizes (Standard length - SL) are expressed as mean \pm SD. * not sampled in April 2006.

\begin{tabular}{|c|c|c|c|c|c|c|c|c|c|c|c|c|c|c|}
\hline \multicolumn{3}{|c|}{ Species } & \multicolumn{4}{|c|}{ Astyanax aff. bimaculatus } & \multicolumn{4}{|c|}{ Hoplias malabaricus } & \multicolumn{4}{|c|}{ Prochilodus brevis } \\
\hline Area & Site & Occasion & $\mathrm{N}$ & $\mathrm{A}$ & $\mathrm{U}$ & $\mathrm{SL}( \pm \mathrm{SD})$ & $\mathrm{N}$ & $\mathrm{A}$ & $\mathrm{U}$ & $\mathrm{SL}( \pm \mathrm{SD})$ & $\mathrm{N}$ & $\mathrm{A}$ & $\mathrm{U}$ & $\mathrm{SL}( \pm \mathrm{SD})$ \\
\hline \multirow[t]{12}{*}{ Seridó/Borborema } & Seridó stream & April & 194 & 15 & 12 & $2.69( \pm 0.17)$ & 1 & 1 & 0 & - & 5 & 4 & 4 & $4.95( \pm 0.38)$ \\
\hline & (SE) & June & 142 & 15 & 15 & $4.59( \pm 0.55)$ & 17 & 12 & 7 & $13.44( \pm 1.17)$ & 15 & 8 & 7 & $7.65( \pm 1.13)$ \\
\hline & & October & 206 & 15 & 11 & $5.51( \pm 0.48)$ & 31 & 15 & 13 & $10.51( \pm 1.21)$ & 164 & 15 & 9 & $7.55( \pm 0.35)$ \\
\hline & & December & 0 & - & - & - & 4 & 4 & 4 & $14.37( \pm 2.31)$ & 59 & 15 & 15 & $12.25( \pm 4.09)$ \\
\hline & Cipó stream & April & 19 & 10 & 8 & $3.8( \pm 0.48)$ & 5 & 3 & 2 & $3.40( \pm 0.07)$ & 0 & - & - & - \\
\hline & (CP) & June & 5 & 3 & 3 & $5.26( \pm 0.25)$ & 10 & 5 & 2 & $9.25( \pm 0.77)$ & 5 & 3 & 3 & $9.76( \pm 0.83)$ \\
\hline & & October & 16 & 10 & 4 & $3.35( \pm 0.47)$ & 4 & 3 & 2 & $8.35( \pm 6.01)$ & 0 & - & - & - \\
\hline & & December & 0 & - & - & - & 2 & 2 & 1 & $17.10( \pm 0.00)$ & 0 & - & - & - \\
\hline & Recanto Reservoir & April & 23 & 15 & 15 & $4.46( \pm 1.31)$ & 0 & - & - & - & 1 & 1 & 1 & $5.70( \pm 0.00)$ \\
\hline & (RE) & June & 46 & 15 & 15 & $5.44( \pm 0.34)$ & 2 & 2 & 1 & $15.80( \pm 0.00)$ & 2 & 2 & 2 & $17.90( \pm 2.12)$ \\
\hline & & October & 234 & 15 & 14 & $4.87( \pm 0.28)$ & 20 & 9 & 9 & $3.48( \pm 0.31)$ & 0 & - & - & - \\
\hline & & December & 394 & 15 & 14 & $5.35( \pm 0.44)$ & 9 & 8 & 7 & $8.85( \pm 7.72)$ & 3 & 2 & 2 & $17.80( \pm 1.27)$ \\
\hline \multirow[t]{11}{*}{ Buíque/Vale do Ipojuca } & *Escama-Peixe stream & June & 44 & 15 & 14 & $5.35( \pm 0.68)$ & 0 & - & - & - & 9 & 5 & 4 & $14.85( \pm 2.98)$ \\
\hline & $(\mathrm{EP})$ & October & 75 & 15 & 13 & $5.33( \pm 0.70)$ & 2 & 2 & 1 & $10.00( \pm 0.00)$ & 6 & 5 & 2 & $14.50( \pm 0.42)$ \\
\hline & & December & 7 & 1 & 0 & - & 1 & 1 & 1 & $20.50( \pm 0.00)$ & 0 & - & - & - \\
\hline & Mulungú Reservoir & April & 12 & 8 & 7 & $5.21( \pm 0.66)$ & 0 & - & - & - & 0 & - & - & - \\
\hline & (MU) & June & 99 & 15 & 14 & $4.34( \pm 0.25)$ & 1 & 1 & 1 & $7.00( \pm 0.00)$ & 0 & - & - & - \\
\hline & & October & 511 & 15 & 13 & $5.47( \pm 0.59)$ & 0 & - & - & - & 1 & 1 & 1 & $13.40( \pm 0.00)$ \\
\hline & & December & 235 & 15 & 14 & $4.50( \pm 0.24)$ & 0 & - & - & - & 0 & - & - & - \\
\hline & Gurjão Reservoir & April & 2 & 2 & 1 & $6.10( \pm 0.00)$ & 0 & - & - & - & 0 & - & - & - \\
\hline & $(\mathrm{GU})$ & June & 0 & - & - & - & 0 & - & - & - & 0 & - & - & - \\
\hline & & October & 6 & 4 & 4 & $9.30( \pm 0.28)$ & 0 & - & - & - & 0 & - & - & - \\
\hline & & December & 13 & 8 & 4 & $9.82( \pm 0.77)$ & 0 & - & - & - & 0 & - & - & - \\
\hline SUM & & & 2386 & 226 & 195 & $4.98( \pm 1.33)$ & 109 & 68 & 51 & $9.69( \pm 5.06)$ & 279 & 61 & 50 & $10.66( \pm 4.37)$ \\
\hline
\end{tabular}


Table 2. Percentage of volume (Vol\%) and frequency of occurrence (FO\%) of macroscopic food items found in the diet of Astyanax aff. bimaculatus, Hoplias malabaricus and Prochilodus brevis, in aquatic habitats of the Brazilian semi-arid region. Contribution by percent volume of major categories is also provided.

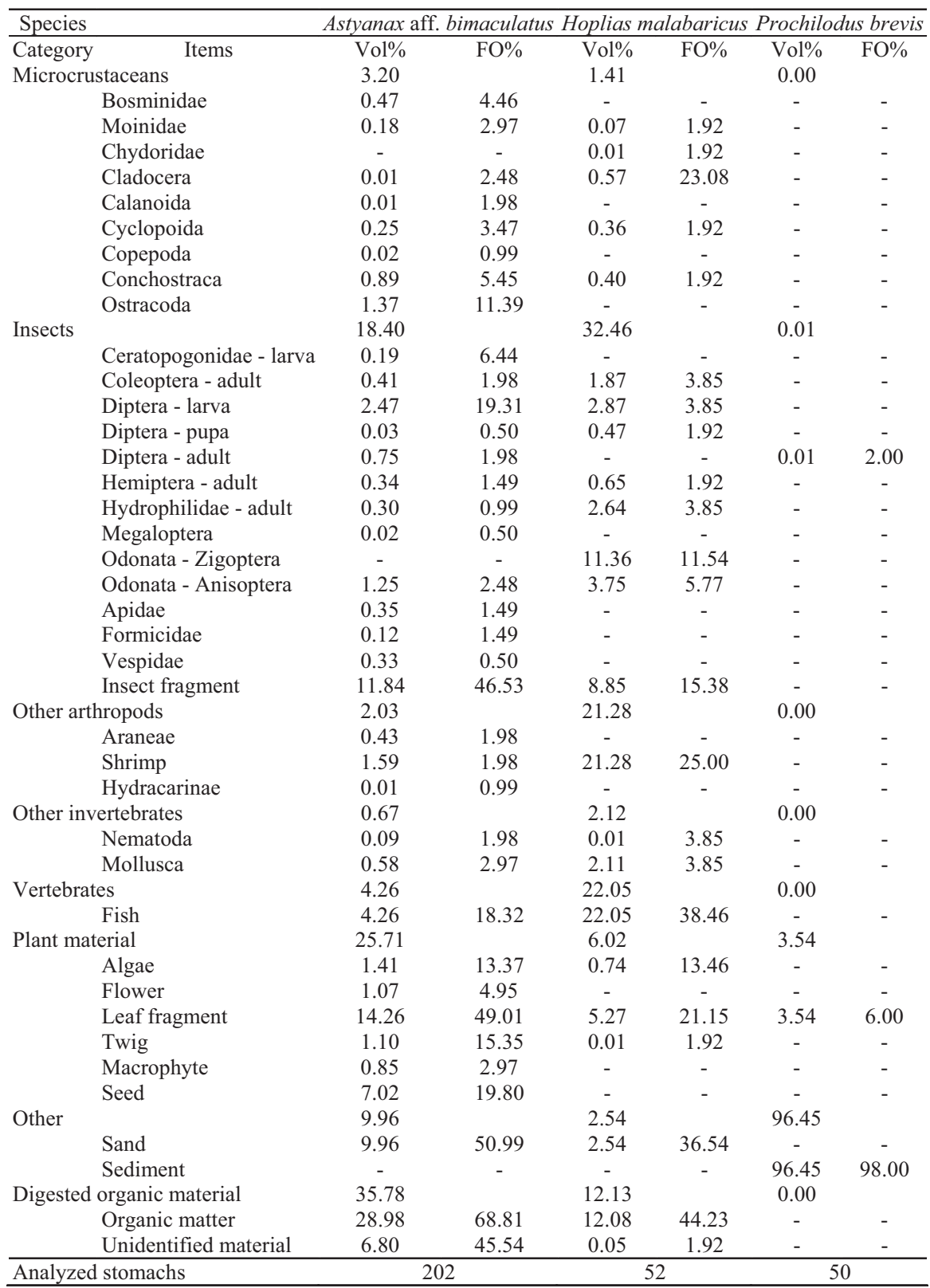

differences in diet composition between stream and reservoir sites (MRPP, $A=0.01$ and $p=0.29$ ). There was dominance of insect and leaf fragments and sand in the $\operatorname{diet}$ of $A$. aff. bimaculatus throughout the study sites and sampling occasions (Fig. 3).

\section{Discussion}

Tropical aquatic systems are known for the wide range of fish species adapted to consume resources from very different sources, from the bottom dwellers that feed on detritus and algae to the large predators in the water column (LoweMcConnell, 1987). As expected from dietary data available for
A. aff. bimaculatus, H. malabaricus and P. brevis (Paiva, 1974; Bayo \& Yuan, 1996; Soares \& Rosa, 1998; Meschiatti et al., 2000; Gurgel et al., 2002), the three species showed different diet composition based on insects and plant material $(A$. aff. bimaculatus), fish and shrimp (H. malabaricus) and sediment/ microalgae $(P$. brevis), reflecting differences in specific morphological and behavioral characteristics.

Overall, the study species showed high rates of stomach fullness. Hoplias malabaricus in particular presented very high stomach fullness when compared to other studies (Loureiro \& Hahn, 1996; Carvalho et al., 2002). Even though the degree of fullness gives no indication of the nutritional value (or quality) of the food ingested, it indicates that food resources were 
Table 3. Relative abundance (A\%) and frequency of occurrence (FO\%) of microscopic food items found in the diet of Prochilodus brevis, in aquatic habitats of the Brazilian semi-arid region.

\begin{tabular}{|c|c|c|c|c|c|}
\hline Class/Genus & $\mathrm{A} \%$ & $\mathrm{FO} \%$ & Class/Genus & $\mathrm{A} \%$ & $\mathrm{FO} \%$ \\
\hline Bacillariophyceae & & & Coscinodiscophyceae & & \\
\hline Achnanthes & 0.28 & 9.09 & Aulacoseira & 0.95 & 9.09 \\
\hline Amphora & 21.96 & 58.18 & Cyclotella & 0.95 & 32.73 \\
\hline Cocconeis & 0.66 & 10.91 & Melosira & 10.88 & 10.91 \\
\hline Cymbella & 1.42 & 25.45 & & & \\
\hline Diploneis & 0.19 & 7.27 & Dinophyceae & & \\
\hline Eunotia & 0.38 & 7.27 & Peridinium & 2.56 & 16.36 \\
\hline Gomphonema & 2.22 & 23.64 & Protoperidinium & 0.05 & 1.82 \\
\hline Gyrosigma & 0.38 & 10.91 & & & \\
\hline Navicula & 4.64 & 36.36 & Euglenophyceae & & \\
\hline Nitzschia & 0.47 & 14.55 & Euglena & 0.76 & 20.00 \\
\hline Pinnularia & 0.57 & 10.91 & Lepocinclis & 0.14 & 5.45 \\
\hline Stauroneis & 0.66 & 12.73 & Phacus & 0.57 & 12.72 \\
\hline \multirow[t]{2}{*}{ Surirella } & 0.14 & 3.64 & Strombomonas & 0.28 & 9.09 \\
\hline & & & Trachelomonas & 2.37 & 45.45 \\
\hline \multicolumn{6}{|l|}{ Chlamydophyceae } \\
\hline Chlamydomonas & 0.14 & 3.64 & Fragilariophyceae & & \\
\hline & & & Fragilaria & 8.71 & 70.91 \\
\hline Chlorophyceae & & & Staurosirella & 0.05 & 1.82 \\
\hline Actinastrum & 0.05 & 182 & Synedra & 0.76 & 5.45 \\
\hline Botryococcus & 0.09 & 1.82 & & & \\
\hline Chlorococcum & 0.14 & 1.82 & Oedogoniophyceae & & \\
\hline Coelastrum & 0.80 & 21.82 & Oedogonium & 0.38 & 7.27 \\
\hline Crucigenia & 0.47 & 12.73 & & & \\
\hline Micractinium & 0.05 & 1.82 & Xanthophyceae & & \\
\hline Monoraphidium & 1.42 & 21.82 & Centritractus & 0.14 & 5.45 \\
\hline Oocystis & 0.19 & 7.27 & & & \\
\hline Pediastrum & 0.24 & 7.27 & Zygnemaphyceae & & \\
\hline Scenedesmus & 12.16 & 65.45 & Closterium & 0.05 & 1.81 \\
\hline Schroederia & 0.05 & 1.82 & Cosmarium & 0.14 & 3.63 \\
\hline Sorastrum & 0.05 & 1.82 & Eaustrum & 0.05 & 1.81 \\
\hline Tetraedron & 2.51 & 36.36 & Mougeotia & 1.00 & 1.82 \\
\hline \multirow[t]{2}{*}{ Tetrastrum } & 0.57 & 12.73 & Octacanthium & 0.28 & 7.27 \\
\hline & & & Spirogyra & 0.24 & 1.81 \\
\hline Cyanophyceae & & & Staurastrum & 0.24 & 3.64 \\
\hline Anabaenopsis & 0.05 & 1.81 & & & \\
\hline Aphanocapsa & 0.14 & 5.45 & & & \\
\hline Chroococcus & 0.28 & 7.27 & & & \\
\hline Coelomoron & 0.09 & 1.82 & & & \\
\hline Coelosphaerium & 0.19 & 5.45 & & & \\
\hline Eucapsis & 0.05 & 1.81 & & & \\
\hline Johannesbaptista & 0.43 & 9.09 & & & \\
\hline Merismopedia & 0.19 & 7.27 & & & \\
\hline Oscillatoria & 13.96 & 60.00 & & & \\
\hline Planktothrix & 0.05 & 1.81 & & & \\
\hline Pseudoanabaena & 0.76 & 9.09 & & & \\
\hline Romeria & 0.09 & 1.81 & & & \\
\hline Spirulina & 0.24 & 7.27 & & & \\
\hline
\end{tabular}

quantitatively available during the study period. Furthermore, stomach fullness may indicate abundance of resources available at a species niche and the level of competition for food (Berg, 1979). The high rates of stomach fullness registered in the present study may result from the presence of preferential food and an abundance of food items easily detected and consumed by the study species, and can indicate low competition in each particular level of the food chain.

Regarding the nature of the food consumed, $A$. aff. bimaculatus showed the most diverse diet among the study species. Even though differences in taxonomic resolution hampers specific comparisons, the number of food items consumed by $A$. aff. bimaculatus in the present study is in

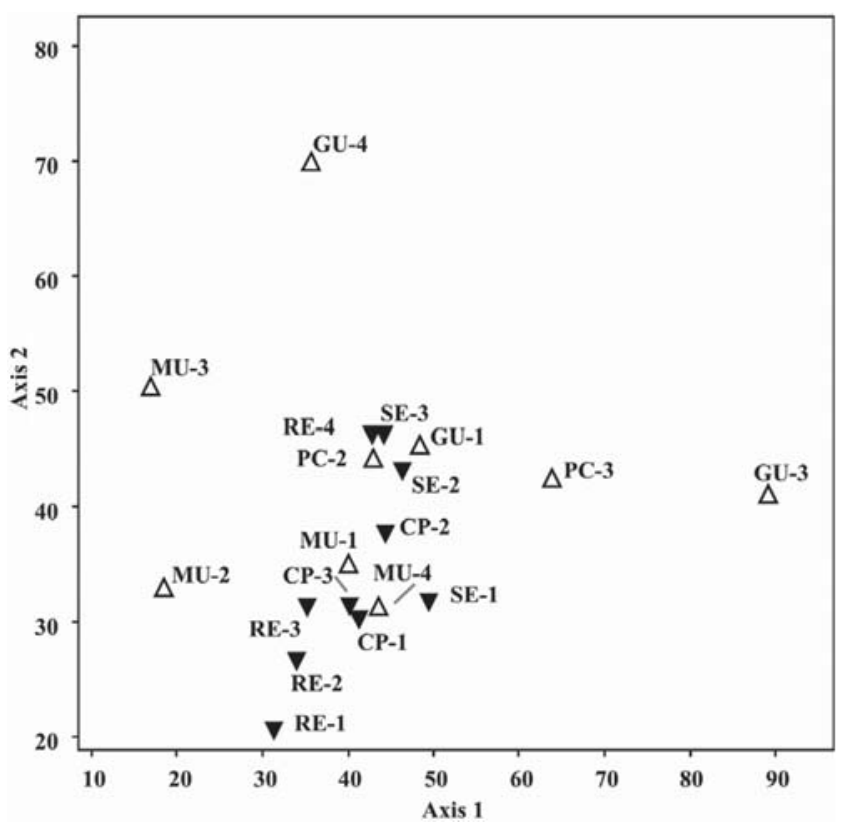

Fig. 2. DCA plot for food items found in the diet of Astyanax aff. bimaculatus, in aquatic habitats of the Brazilian semi-arid region. $\boldsymbol{\nabla}=$ Seridó/Borborema and $\Delta=$ Buíque/Vale do Ipojuca. Codes represent sampling sites (Table 1) and sampling occasions (1 - April, 2 - June, 3 - October, and 4 - December).

accordance with other studies performed on species of the same genus in northeastern Brazil (Silva, 2008; Mendes et al., 2009) and in more humid areas (Vilella et al., 2002; Bennemann et al., 2005). The diet composition of $A$. aff. bimaculatus is also similar to these studies, which report a diet based on plant material, insects, bottom detritus and sediment.

This species has been reported as an opportunistic feeder, capable of consuming a large variety of food items (Vilella et al., 2002). As such, it should be expected that $A$. aff. bimaculatus would change its diet according to variations in the habitat and seasons as different food resources become available. However, multivariate analyses showed that diet was similar across study areas and habitat types, indicating that food resources may not change between the different types of habitat studied and/or seasons. Nevertheless, such a view is not supported by data on the structure of the habitat in the study sites (Medeiros et al., 2008). The structure of the habitat has been reported as a framework for colonization of the aquatic fauna and flora (Martin-Smith, 1998) which in turn sustains fish consumers (Mugodo et al., 2006; Beltrão et al., 2009). According to Medeiros et al. (2008) the habitat structure of the study sites was different between streams and reservoirs and between dry and wet seasons, and important elements separating these groups were aquatic macrophytes, marginal vegetation and the substrate composition. An explanation for the conservative diet, in this case, could be that resources available are abundant and diverse, and $A$. aff. bimaculatus chose the food items of its preference across study habitats. 


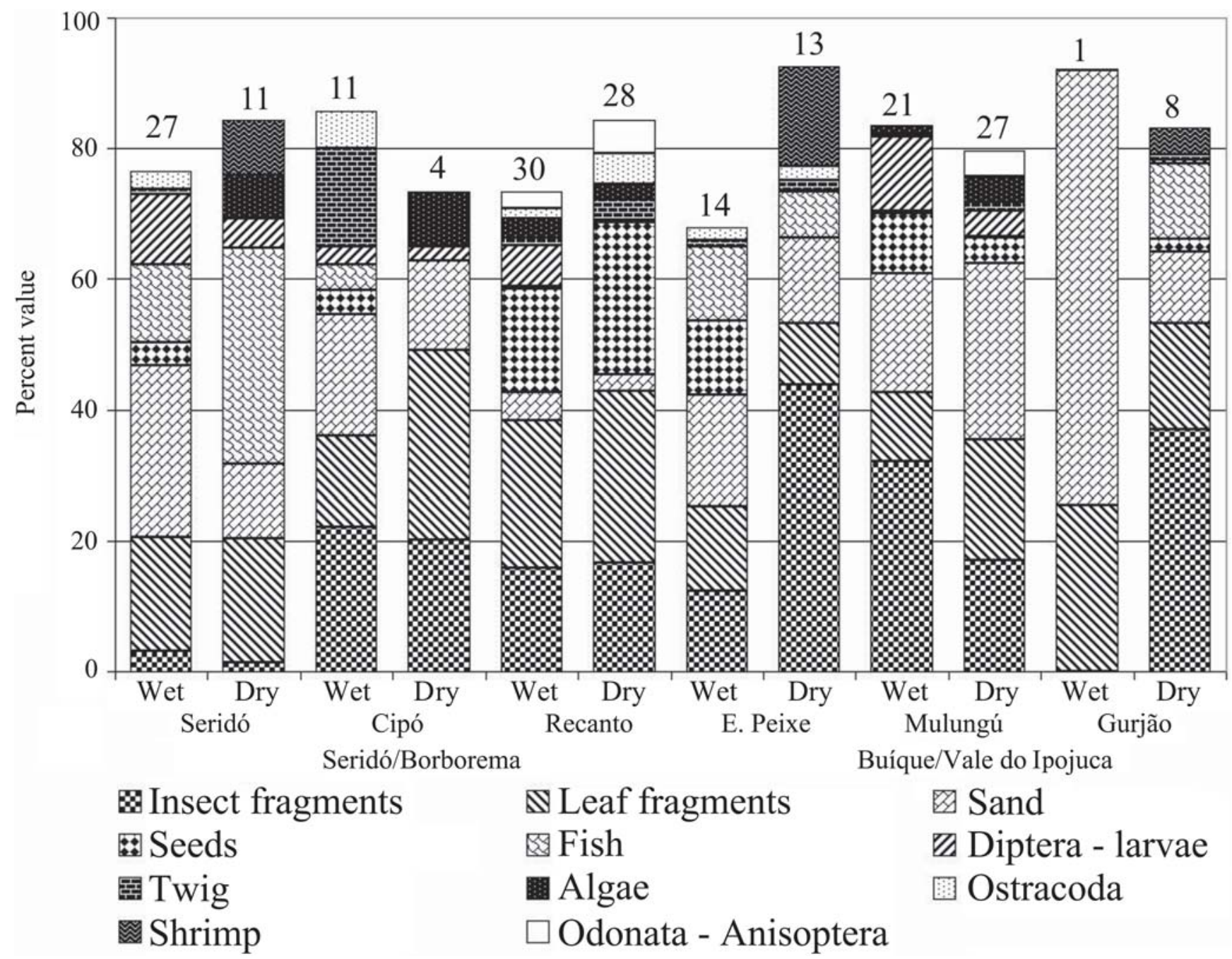

Fig. 3. Percentage composition of main food items to the diet of Astyanax aff. bimaculatus. Number of stomachs used ( $>20 \%$ fullness) is shown above each column.

Some studies characterize $H$. malabaricus as a carnivorous species with a diet based on fish (Loureiro \& Hahn, 1996; Carvalho et al., 2002). Dietary needs of $H$. malabaricus in the present study were more specific compared to $A$. aff. bimaculatus, but it was more diverse than that described in some other studies (Loureiro \& Hahn, 1996; Carvalho et al., 2002). In the present study, the diet based on insects, shrimp and fish is likely to be a consequence of the relatively small size of fish analyzed, rarely greater than $20 \mathrm{~cm}$ (SL). Winemiller (1989) reported a shift in the diet of $H$. malabaricus, from microcrustaceans and aquatic insects in smaller individuals $(<5 \mathrm{~cm})$ to fish in larger individuals.

Hoplias malabaricus is known for the tolerance to food deprivation, being able to overcome severe food scarcity during dry periods (Rios et al., 2004). Even though this species tends to swallow whole preys, a great percentage of nearly empty stomachs for the species has been reported (Paiva, 1974; Bistoni et al., 1995). During the present study $H$. malabaricus presented a diverse diet, and there was little indication that the species had food limitations, since the percentage of empty stomachs was low (16.1\%) when compared to other studies. Some of them have registered as much as $70 \%$ of empty stomachs (e.g. Loureiro \& Hahn, 1996; Carvalho et al., 2002). It is important to explain that the studies cited analyzed larger individuals, and younger $H$. malabaricus tend to feed more frequently.

The present study showed a great contribution of bottom sediment $(>95.0 \%)$ to the diet of P. brevis. The high consumption of sediment is clearly associated with the ingestion of microalgae, as shown by the microscopic analysis of the sediment ingested. The presence of grit in the stomach of detritivorous species has also been known to aid grinding of particulate organic matter. A description of spatial and temporal variations in the composition of microalgae consumed by $P$. brevis in aquatic systems of semi-arid Brazil is given in detail by Figueiredo et al. (2009). The study reports greater abundance of Bacillariophyceae during the wet season and in individuals caught in reservoirs, whereas larger amounts of Chlorophyceae were consumed during the dry season. A greater 
diversity of classes was consumed in stream sites (Bacillariophyceae, Chlorophyceae, Coscinodiscophyceae, Cyanophyceae, and Fragilariophyceae) (Figueiredo et al., 2009). According to these authors, resource availability is an important element affecting composition of the microscopic component of the diet of $P$. brevis. This is in accordance with Medeiros et al. (2008) who reported a high complexity of the aquatic habitat and important spatio-temporal variations of the mud- and sand-dominated bottom substrate in aquatic systems of semi-arid Brazil.

In conclusion, we observed a wide range of food items consumed by these fish species (varying from microalgae to fish). Furthermore, each of the study species showed specific dietary needs with predominance of some food items. These results and the relatively high rates of stomach fullness indicate that a diverse and abundant food range is available in the study sites, but species seem to select some resources. This is likely to be the result of natural variations in abundance of specific food items associated with fish preferences. Present results provide evidence that aquatic habitats in semi-arid Brazil, being artificial reservoirs or natural intermittent streams, are capable of supporting fish consumers at different trophic levels. These sites can support generalist species such as $A$. aff. bimaculatus as well as fish species with more specific dietary needs, such as $P$. brevis (which feeds mostly on microalgae) and $H$. malabaricus, a predator that feeds mostly on fish and shrimp.

\section{Acknowledgements}

The authors are grateful to Telton Pedro Anselmo Ramos and Virginia Dantas Diniz (UFPB) for support during the fieldwork and for helping with the identification of fish, and to Gabrielle Joanne Medeiros Araujo (UEPB) for helping with the identification of algae. ESFM is grateful to CNPq/UEPB/ DCR for the scholarship granted (350082/2006-5). MJS is grateful to "Programa de Iniciação Científica da UEPB/CNPq" for the scholarship granted (PROINCI/UEPB 2006-2007 and PIBIC/CNPq/UEPB 2007-2008)". This research was supported by FAPESQ/UEPB (68.0006/2006.0) and "Projeto de Pesquisa em Biodiversidade do Semi-árido (PPBio Semiárido)".

\section{Literature Cited}

Abell, R., M. L. Thieme, C. Revenga, M. Bryer, M. Kottelat, N. Bogutskaya, B. Coad, N. Mandrak, S. C. Balderas, W. Bussing, M. L. J. Stiassny, P. Skelton, G. R. Allen, P. Unmack, A. Naseka, R. Ng, N. Sindorf, J. Robertson, E. Armijo, J. V. Higgins, T. J. Heibel, E. Wikramanayake, D. Olson, H. L. López, R. E. Reis, J. G. Lundberg, M. H. S. Pérez \& P. Petry. 2008. Freshwater ecoregions of the world: a new map of biogeographic units for freshwater biodiversity conservation. BioScience, 58: 403-414.

Amorim, I. L., E. V. S. B. Sampaio \& E. L. Araújo. 2005. Flora e estrutura da vegetação arbustivo-arbórea de uma área de Caatinga do Seridó, RN, Brasil. Acta Botânica Brasileira, 19(3): 615-623.

Arthington, A. H. 1992. Diets and trophic guild structure of freshwater fishes in Brisbane streams. Proceedings of the Royal Society of Queensland, 102: 31-47.
Bayo, V. \& E. C. Yuan. 1996. Food assimilation of a neotropical riverine detritivorous fish, Prochilodus lineatus, studied by fatty acid composition (Pisces, Curimatidae). Hydrobiologia, 330: 81-88.

Beltrão, G. B. M., E. S. F. Medeiros \& R. T. C. Ramos. 2009. Effects of riparian vegetation on the structure of the marginal aquatic habitat and the associated fish assemblage in a tropical Brazilian reservoir. Biota Neotropica, 9(4): 37-43.

Bennemann, S. T., A. M. Gealh, M., L. Orsi \& L. M. Sousa. 2005. Ocorrência e ecologia trófica de quatro espécies de Astyanax (Characidae) em diferentes rios da bacia do rio Tibagi, Paraná, Brasil. Iheringia, Série Zoologia, 95(3): 247-254.

Berg, J. 1979. Discussion of methods of investigating the food of fishes, with reference to a preliminary study of the prey of Gobiusculus flavescens (Gobiidae). Marine Biology 50: 263273.

Bicudo, C. E. M. \& M. Menezes. 2006. Gêneros de Algas de águas continentais do Brasil. RIMA, 508p.

Bistoni, M. A., J. G. Haro \& M. Gutierréz. 1995. Feeding of Hoplias malabaricus in the wetlands of Dulce river (Cordoba, Argentina). Hydrobiologia, 316: 103-107.

Carvalho, L. N., C. H. V. Fernandes \& V. S. S. Moreira. 2002. Alimentação de Hoplias malabaricus (Bloch, 1794) (Osteichthyes, Erythrinidae) no rio Vermelho, Pantanal Sul Mato-Grossense. Revista Brasileira de Zoociências, 4: 227236.

Chaves, M. F., J. Torelli, C. H. Targino \& M. C. Crispim. 2009. Dinâmica reprodutiva e estrutura populacional de Hoplias aff. malabaricus (Bloch, 1794) (Characiformes, Erythrinidae), em açude da Bacia do Rio Taperoá, Paraíba. Biotemas, 22: 85-89.

Figueiredo, B. R. S., G. J. M. Araujo, M. J. Silva \& E. S. F. Medeiros. 2009. Análise da alimentação de Prochilodus brevis (Steindachner 1874), (Characiformes: Prochilodontidae) em ambientes aquáticos do semiárido brasileiro. In: Anais do IX Congresso de Ecologia do Brasil. São Lourenço-MG, 5p.

Governo do Estado da Paraíba. 1985. Atlas geográfico do Estado da Paraíba. Grafset, 100p.

Gurgel, H. C. B., F. D. Lucas \& L. L. G. Souza. 2002. Dieta de sete espécies de peixes do semi-árido do Rio Grande do Norte, Brasil. Revista de Ictiologia, 10(1/2): 7-16.

Hyslop, E. J. 1980. Stomach contents analysis - a review of methods and their application. Journal of Fish Biology, 17(4): 411-429.

Humphries, P. \& P. S. Lake. 2000. Fish larvae and the management of regulated rivers. Regulated Rivers: Research \& Management, 6: 421-432.

Leal, I. R., J. M. C. Silva \& M. Tabarelli (Ed.). 2003. Ecologia e Conservação da Caatinga. EDUFPE, 135-181.

Leal, I. R., J. M. C. Silva, M. Tabarelli \& T. E. Lacher Jr. 2005. Changing the course of biodiversity conservation in the Caatinga of northeastern Brazil. Conservation Biology, 19: 701-706.

Loureiro, V. E. \& N. S. Hahn. 1996. Dieta e atividade da traíra, Hoplias malabaricus (Bloch, 1794) (Osteichthyes, Erythrinidae), nos primeiros anos de formação do reservatório de Segredo (PR). Acta Limnologica Brasiliensia, 8: 195-205.

Lowe-McConnell, R. H. 1987. Ecological Studies in Tropical Fish Communities. Cambridge University Press, London.

Magoulick, D. D. \& R. M. Kobza. 2003. The role of refugia for fishes during drought: a review and synthesis. Freshwater Biology, 48: 1186-1198.

Maltchik, L. 1996. Perturbação hidrológica e zona hiporreica: conceitos basicos para pesquisas nos rios temporários do semiárido brasileiro. Revista Nordestina de Biologia, 11: 1-13. 
Maltchik, L. \& E. S. F. Medeiros. 2006. Conservation importance of semi-arid streams in north-eastern Brazil: implications of hydrological disturbance and species diversity. Aquatic Conservation: Marine and Freshwater Ecosystems, 16: 665-677.

Martin-Smith, K. M. 1998. Relationships between fishes and habitat in rainforest streams in Sabah, Malaysia. Journal of Fish Biology, 52(3): 458-482.

McCune, B. \& J. B. Grace. 2002. Analysis of Ecological Communities. Gleneden Beach, Oregon, U.S.A, MjM Software Design, 300p.

McCune, B. \& M. J. Mefford. 1999. PC-ORD. Multivariate Analysis of Ecological Data. Version 4.27. Gleneden Beach, Oregon, U.S.A, MjM Software Design.

Medeiros, E. S. F. \& A. H. Arthington. 2008a. Diel variation in food intake and diet composition of three native fish species in floodplain lagoons of the Macintyre River, Australia. Journal of Fish Biology, 73(4): 1024-1032.

Medeiros, E. S. F. \& A. H. Arthington. 2008b. The importance of zooplankton in the diets of three native fish species in floodplain waterholes of a dryland river, the Macintyre River, Australia. Hydrobiologia, 614: 19-31.

Medeiros, E. S. F. \& L. Maltchik. 2000. Influence of hydrological disturbance on reproduction of a fish community in an intermittent stream from Brazilian semiarid region. Verhandlungen der Internationalen Vereinigung für theoretische und angewandte Limnologie, 27: 906-911.

Medeiros, E. S. F. \& L. Maltchik. 2001a. Diversity and stability of fishes (Teleostei) in a temporary river of the Brazilian semiarid region. Iheringia, Série Zoologia, 90: 157-166.

Medeiros, E. S. F. \& L. Maltchik. 2001b. Fish assemblage stability in an intermittently flowing stream from the Brazilian semiarid region. Austral Ecology, 26(2): 156-164.

Medeiros, E. S. F., R. T. C. Ramos, T. P. A. Ramos \& M. J. Silva. 2006. Spatial variation in reservoir fish assemblages along semi-arid intermittent river, Curimataú River, northeastern Brazil. Revista de Biologia e Ciências da Terra Suplemento especial, 1: 29-39.

Medeiros, E. S. F., M. J. Silva \& R. T. C. Ramos. 2008. Application of catchment- and local-scale variables of aquatic habitat characterization and assessment in the Brazilian Semi-arid Region. Neotropical Biology and Conservation, 3(1): 13-20.

Medeiros, E. S. F., M. J. Silva, B. R. S. Figueiredo, T. P. A. Ramos \& R. T. C. Ramos. 2010. Effects of fishing technique on assessing species composition in aquatic systems in semi-arid Brazil. Brazilian Journal of Biology, 70(2): 255-262.

Mendes, L. B., E. S. F. Medeiros, M. J. Silva \& R. T. C. Ramos. 2009. Análise quantitativa da dieta de Astyanax fasciatus (Cuvier, 1819), (Characiformes Characidae) em um rio intermitente do semiárido brasileiro. In: Anais do IX Congresso de Ecologia do Brasil. São Lourenço-MG, 5p.

Meschiatti, A. J., M. S. Arcifa \& N. Fenerich-Verani. 2000. Fish communities associated with macrophytes in Brazilian floodplain lakes. Environmental Biology of Fishes, 58: 133-143.

Mugodo, J., M. J. Kennard, P. Liston, S. Nichols, S. Linke, R. H. Norris \& M. Lintermans. 2006. Local stream habitat variables predicted from catchment scale characteristics are useful for predicting fish distribution. Hydrobiologia, 572: 59-70.
Paiva, M. P. 1974. Crescimento, alimentação e reprodução da traíra, Hoplias malabaricus (Bloch) no Nordeste brasileiro, Fortaleza-CE. Unpublished Ph.D. Dissertation. Universidade Federal de São Carlos, São Carlos, 32p.

Paiva, M. P. \& E. Campos. 1995. Fauna do Nordeste do Brasil. Conhecimento científico e popular. Banco do Nordeste do Brasil, 274p.

Peel, M. C., B. L. Finlayson \& T. A. McMahon. 2007. Updated world map of the Köppen-Geiger climate classification. Hydrology and Earth System Sciences, 11(5): 1633-1644.

Pusey, B. J., A. H. Arthington \& M. G. Read. 1995. The feeding ecology of freshwater fishes in two rivers of the Australian wet tropics. Environmental Biology of Fishes, 43(1): 85-103.

Pusey, B. J., A. H. Arthington \& M. G. Read. 2000. The dry season diet of freshwater fishes in monsoonal tropical rivers of Cape York Peninsula, Australia. Ecology of Freshwater Fish, 9(3): 177-190.

Rios, F. S., A. L. Kalinin, M. N. Fernandes \& F. T. Rantin. 2004. Changes in gut gross morphology of traíra, Hoplias malabaricus (Teleostei, Erythrinidae) during long-term starvation and after refeeding. Brazilian Journal of Biology, 64(3b): 683-689.

Rodal, M. J. N., K. V. A. Andrade, M. F. Sales \& A. P. S. Gomes. 1998. Fitossociologia do componente lenhoso de um refúgio vegetacional no município de Buíque, Pernambuco. Revista Brasileira de Biologia, 58(3): 517-526.

Rosa, R. S., N. A. Menezes, H. A. Britski, W. J. E. M. Costa \& F. Groth. 2003. Diversidade, padrões de distribuição e conservação dos peixes da Caatinga. Pp. 135-181. In: Leal, I. R., J. M. C. Silva \& M. Tabarelli (Eds.). 2003. Ecologia e Conservação da Caatinga: Peixes da Caatinga. EDUFPE, 806p.

Silva, D. A. 2008. Ecologia alimentar e reprodutiva da piaba-dorabo-amarelo, Astyanax cf. lacustris (Reinhardt, 1874) (Osteichthyes: Characidae) na Lagoa do Piató, Assu, Rio Grande do Norte, Brasil. Unpublished Masters Dissertation, Universidade Federal do Rio Grande do Norte.

Silva, J. M. C., M. Tabarelli, M. T. D. Fonseca \& L. V. Lins (Ed.). 2003. Biodiversidade da Caatinga: áreas e ações prioritárias para a conservação. Brasília-DF, Ministério do Meio Ambiente. UFPE, 382p.

Soares, R. R. \& I. L. Rosa. 1998. Alimentação e crescimento de Prochilodus brevis Steindachner, 1874 (Characiformes: Prochilodontidae) no rio Gramame, Paraíba, Brasil. Revista Nordestina de Biologia, 12(1/2): 49-60.

Tabarelli, M. \& J. M. C. Silva. 2003. Áreas e ações prioritárias para a conservação da biodiversidade da Caatinga. Pp. 777-796. In: Leal, I. R., J. M. C. Silva \& M. Tabarelli (Eds.). 2003. Ecologia e Conservação da Caatinga. EDUFPE, 806p.

Vilella, F. S., F. G. Becker \& S. M. Hartz. 2002. Diet of Astyanax species (Teleostei, Characidae) in an Atlantic Forest River in Southern Brazil. Brazilian Archives of Biology and Technology, 45: 223-232

Winemiller, K. O. 1989. Ontogenetic diet shifts and resource partitioning among piscivorous fishes in the Venezuelan ilanos. Environmental Biology of Fishes, 26: 177-199.

Zavala-Camin L. A. 1996. Introdução aos estudos sobre alimentação natural em peixes. Eduem, Maringá. 129p. 